\title{
PERTUNJUKAN SIDALUPA BURAQ LAM TAPA DI BUBON-ACEH BARAT DALAM PERSPEKTIF PERFORMANCE STUDIES
}

\author{
Susandro $^{1^{*}}$, Hatmi Negria Taruan ${ }^{2 *}$ \\ Program Studi Seni Teater Jurusan Seni Pertunjukan ${ }^{{ }^{*}}$, Program Studi Seni Rupa \\ Jurusan Seni Rupa dan Desain ${ }^{2 *}$ \\ Institut Seni Budaya Indonesia Aceh \\ Jl. Transmigrasi, Gampong Bukit Meusara, Kec. Kota Jantho, Kab. Aceh Besar, Kode Pos 23911 \\ Aceh. Indonesia \\ Email: susandro@isbiaceh.ac.id,hatminegriataruan@isbi.ac.id
}

\begin{abstract}
Abstrak
Artikel ini bertujuan menyelisik kesenian Sidalupa Buraq Lam Tapa di Bubon-Aceh Barat dari berbagai sisi menggunakan kacamata performance studies. Metode yang diterapkan yakni kualitatif dengan teknik studi pustaka atau pengumpulan data dokumen, observasi, wawancara, dan perekaman audiovideo. Hasil yang diperoleh ialah masyarakat (penonton) juga menjadi penentu keberadaan dan keberlangsungan kesenian Sidalupa, karena kesenian ini selalu mengisi setiap acara yang diselenggarakan oleh masyarakat. Dalam arti kata lain, kesenian ini digelar berdasarkan permintaan atau undangan dari masyarakat. Cukup tingginya minat masyarakat terhadap Sidalupa disebabkan karena kesenian ini dapat menghibur tamu atau penonton di setiap acara yang diselenggarakan, baik acara sunat rasul, akikah, pernikahan, serta acara adat lainnya, bahkan dalam acara kampanye, pawai dan semacamnya. Namun, pergelaran Sidalupa tidak hanya mengisi panggung atau ruang yang berorientasi pada hiburan semata, melainkan juga hadir pada ruang yang beroirentasi pada nilai estetik dan artistik, seperti acara khusus kesenian dan semacamnya, baik di tingkat lokal maupun nasional. Lebih jauh, beranjak dari apresiasi masyarakat yang demikian, sementara dapat ditarik kesimpulan bahwa pertunjukan kesenian Sidalupa merupakan perhelatan yang dilakoni oleh setiap lini masyarakat. Karena Sidalupa tidak hanya sebatas kesenian, tetapi juga identitas masyarakat pemiliknya.
\end{abstract}

Kata Kunci: sidalupa, penonton, kajian performance.

\begin{abstract}
This article aims to investigate the art of Sidalupa Buraq Lam Tapa in Bubon-West Aceh from various perspectives using the perspective of performance studies. The method applied is qualitative with literature study or document data collection, observation, interviews, and audio-video recording. The results obtained are that the community (the audience) is also a determinant of the existence and sustainability of Sidalupa art, because this art always fills every event organized by the community. In other words, this art is held based on requests or invitations from the community. The high level of public interest in Sidalupa is due to the fact that this art can entertain guests or spectators at every event that is held, whether the apostle's circumcision, akikah, weddings, and other traditional events, even in campaign events, parades and the like. However, the Sidalupa performance does not only fill the stage or space that is oriented towards entertainment alone, but also exists in spaces that are oriented to aesthetic and artistic values, such as special arts events and the like, both at local and national levels. Furthermore, departing from the appreciation of the community, while it can be concluded that the Sidalupa art performance is an event that is carried out by every line of society. Because Sidalupa is not only limited to art, but also the identity of the community that owns it.
\end{abstract}

Keywords: sidalupa, audience, performance studies.

\section{PENDAHULUAN}

Sidalupa merupakan kesenian tradisional yang muncul di tengah masyarakat Aceh Barat dan Aceh Jaya. Tidak dapat diketahui pasti tahun dan di mana mula asalnya, namun perkembangannya cukup masif di Aceh Barat dilihat dari banyaknya jumlah grup Sidalupa di sana (Susandro, 2021: 45). Nama Sidalupa merupakan gabungan dari bahasa lokal Aceh dengan bahasa Indonesia. Da (bahasa Aceh) berarti kakak, sedangkan lupa (Bahasa Indonesia) atau tuwo (Bahasa Aceh) berarti tidak ingat. Secara umum diartikan oleh masyarakat, terutama oleh senimannya sendiri, yakni kakak lupa adik dan adik lupa kakak. Penamaan demikian merupakan hal yang terbilang lazim di Aceh, karena dalam kesehariannya, masyarakatnya menggunakan bahasa lokal/daerah dan bahasa Indonesia sekaligus (Susandro, 2021: 17). Dalam penyebutannya, sebagian menyebut dengan 'Dalupa' 
Gorga : Jurnal Seni Rupa

Volume 10 Nomor 02 Juli-Desember 2021

p-ISSN: 2301-5942 | e-ISSN: 2580-2380

dan sebagian lagi 'Si Dalupa'. Sedangkan dalam penulisannya, ada yang menulis dengan 'Sidalupa', 'si Dalupa', 'Si Dalupa', dan 'Sida Lupa'. Penulisan nama terakhir penulis dapati pada naskah (tidak dipublikasikan) yang ditulis oleh Hanafiah - seniman dan salah satu pendiri Sanggar Seni Datok Rimba (selanjutnya disingkat SSDR) di Aceh Barat - yang berjudul "Sida Lupa Datok Rimba". Varian penulisan tersebut juga dapat dilihat dalam buku, jurnal, buletin, artikel yang tersebar luas dalam google maupun pada deskripsi terkait pergelaran Sidalupa yang ada di youtube. Sekiranya varian penyebutan dan penulisan di atas dimaksudkan pada dua hal; 1) sebutan/nama suatu tokoh/karakter dalam kisah, dan 2) untuk menyebut nama kesenian itu sendiri.

Dalam hal per-wujud-annya, masyarakat (terutama penggiat kesenian itu sendiri) memiliki pandangan yang berbeda tentang tokoh Sidalupa. Sebagian beranggapan bahwa Sidalupa merupakan sosok makhluk gaib. Sebagiannya lagi menduga, bahwa Sidalupa adalah sesosok manusia berbulu lebat seperti orang utan (RN, 2016: 27). Sedangkan ilmuan Belanda yang telah cukup lama berdiam di Aceh, bernama Snouck Hurgronje (dalam Dadek, 2015: 454) menyatakan bahwa Sidalupa merupakan sesosok anak lelaki remaja yang membuat/menggunakan kostum dari ijuk agar tidak dapat dikenali untuk menakut-nakuti temannya Begitu pula dengan awal-mula kisahnya, pun berkembang dan beragam.

Cerita Sidalupa telah digarap menjadi pertunjukan seni dramatik (teater) oleh SSDR pada tahun 1988 dalam kegiatan Pekan Kesenian Aceh (PKA). Kemudian kembali dipentaskan dalam kegiatan Pekan Teater Nasional di Samarinda, tahun 2019. Pada kegiatan yang disebutkan terakhir, Marhalim Zaini bertindak sebagai peneliti. Berdasarkan penelitiannya, Zaini menyatakan bahwa dapat dipastikan pertunjukan Sidalupa yang dimainkan oleh SSDR dari Gampong Suak Trieng, Woyla, adalah suatu bentuk pertunjukan teater yang terlihat dari unsur-unsurnya, yaitu terdapat aktor yang memerankan tokoh, pola dramaturgi dari adegan per adegan, adanya dialog dan musik sebagai pendukung suasana, serta terdapat peranan sutradara.

Pada tahun 2020, peneliti pun melakukan penelitian di sanggar yang sama, tidak hanya sekadar meneliti unsurunsur apa saja yang ada di dalam pergelaran kesenian Sidalupa, melainkan bagaimana proses penciptaannya. Singkatnya, penelitian yang Zaini dan peneliti sendiri lakukan, terbatas pada lingkup dramaturgial; apa saja unsur dan bagaimana proses penciptaan pertunjukan kesenian Sidalupa. Sayangnya, kajian dramaturgial ini tidak memberi celah bagi perihal lain yang sekiranya menarik pula untuk dibahas. Ditambah lagi, sebagaimana telah dipahami pada umumnya, penelitian kualitatif tidak memberikan jawaban atau kesimpulan yang mutlak. Oleh karena itu pembacaan terhadap kesenian Sidalupa tetaplah menarik untuk dilanjutkan, karena masih menyisakan potongan-potongan puzzle yang msaih menjadi misteri, tentunya dengan mengarahkan amatan pada kelompok atau sanggar Sidalupa lainnya yang ada di Aceh Barat, dengan asumsi tidak semua pertunjukan Sidalupa dapat dibaca dengan kajian dramaturgial dan masing-masing kelompok kemungkinan memiliki gaya penyajian yang berbeda dengan kelompok lainnya.

Pembacaan tidak hanya terbatas pada ruang lingkup kecil saja (dramaturgial), seperti yang telah dilakukan pada SSDR sebelumnya, melainkan juga membaca kemungkinan-kemungkinan lain yang mendukung atau bahkan menghambat terlaksananya pergelaran Sidalupa. Pembacaan ini bersifat holistik, tidak hanya mengungkap unsur serta proses penciptaannya, tapi mengungkap kemungkinan adanya faktor lain yang sekiranya memberi dampak pada keberadaan kesenian Dalupa. Baik faktor ekonomi, sosial, politik, sejarah, norma adat, agama, keberadaan penonton dan lain sebagainya. Pembacaan lingkup yang luas ini umumnya dikenal dengan istilah performance studies atau kajian pertunjukan, dengan kata lain - meminjam istilah Lono Simatupang - yakni kajian pergelaran.

Adapun objek materialnya ialah pergelaran yang ditampilkan oleh kelompok Buraq Lam Tapa yang bertempat di desa Kuta Padang, Kecamatan Bubon, Aceh Barat. Sanggar ini dipimpin oleh seorang tetua bernama Nurdin, biasa disapa Syekh Din, juga dikenal dengan nama panggung Buraq Tapa. Pemilihan objek material tidak dapat ditetapkan/dikerucutkan secara spesifik, pergelaran mana yang akan diteliti; di mana dan kapan dipentaskan. Hal demikian dikarenakan Syekh Din atau anggota kelompoknya tidak mendokumentasikan (dalam bentuk foto maupun video) setiap pergelaran yang telah mereka lakukan. Maka dari itu, objek material melingkupi setiap pertunjukan yang pernah dilakukan.

\section{KAJIAN TEORI}

Performance studies (kajian pertunjukan) bukanlah suatu disiplin keilmuan yang berdiri sendiri. Disiplin ilmu ini merupakan pertemuan antara ilmu-ilmu seni (tari, teater, film, dan lainnya) dengan antropologi. Gagasan tokoh-tokoh dunia yang bermuara pada disiplin ilmu performance studies ini ialah Victor Turner (Antropolog Budaya Inggris) dan Richard 
Schechner (praktisi dan akademisi teater Amerika). Sedangkan di Indonesia, diusung oleh seorang antropolog dan ilmuan serta kritikus seni, yaitu Lono Simatupang dan Sal Murgiyanto.

Elaborasi dua disiplin ilmu di atas (seni secara umum dengan antropologi) mengindikasikan bahwa performance studies mencari kemungkinan yang lebih luas, perihal apapun yang mungkin saja terkait dengan pertunjukan yang diteliti. Kajian tidak hanya tertuju pada pertunjukan, tetapi juga seluk-beluk yang melatarbelakangi hadirnya pertunjukan tersebut; bagaimana proses garapannya, pandangan dan pengaruh masyarakat (penonton) terhadap pertunjukan tersebut, fungsi-fungsi pertunjukan tersebut di tengah masyarakat, dan lain sebagainya.

Dalam pemahaman performance studies, 'pertunjukan' atau 'pergelaran' dalam bahasa Lono Simatupang, bukan hanya dipahami melulu sebagai peristiwa yang disengaja namun juga pelbagai peristiwa yang dapat 'tergelar' begitu saja dalam kehidupan sehari-hari dalam pelbagai situasi (Pramayoza, 2013: ix). Dalam arti kata lain, Dede menjelaskan, 'seni pergelaran' (performance art) termasuk teater, pada dasarnya berakar pada 'drama sosial,' di mana manusia mengalami situasi dramatis pertama kali, yang kemudian 'tersangatkan' (heightened) menjadi pergelaran 'drama teatrikal.' Senada dengan itu, Jaeni (2014: 4) menyatakan, "kajian seni pertunjukan merupakan ranah yang sangat luas. Seni pertunjukan hadir dari pertunjukan keseharian manusia."

Kedua keterangan terkait akar seni pertunjukan di atas tentunya berpijak dari empunya, yakni Schechner. Sedangkan bagi Schechner sendiri pertunjukan merupakan ranah yang luas dan selalu terkait dengan kejadian, peristiwa yang berada di lingkungan kita. Rekonstruksi pembunuhan, pemilihan kepala desa, kampanye, pemilihan umum, demonstrasi, perayaanperayaan, bahkan proses pembuatan karya seni pertunjukan, olah raga, menurutnya bisa menjadi pertunjukan, tetapi bukanlah seni pertunjukan (Jaeni, 2014: 5). Menurut Schechner, seni pertunjukan akan terlihat dari bobot isi dan kemasannya yang mengandung nilai estetik juga bentuknya nan artistik. Lebih lanjut ia menegaskan, pertunjukan-pertunjukan yang dikategorikan sebagai seni pertunjukan pun bisa dikategorikan sebagai pertunjukan hiburan belaka, misalnya pertunjukan tari dan musik di café dan bar, organ tunggal, musik dangdut dan rock massal; promosi sebuah sponsor perusahaan rokok (Jaeni, 2014: 5-6).
Adapun gagasan Schechner yang peneliti terapkan dalam penelitian ini ialah apa yang ia sebut dengan "konsep jaringan" (the web). Menurut Schechner, melalui cara kerja dan metodenya dalam membaca seni pertunjukan, konsep jaringan - sebagai sebuah sistem cenderung lebih dinamis di setiap interaksi dengan orang lain atau masyarakat. Pada prinsipnya, konsep jaringan Schechner menjelaskan hubungan antarkontinum (rangkaian).

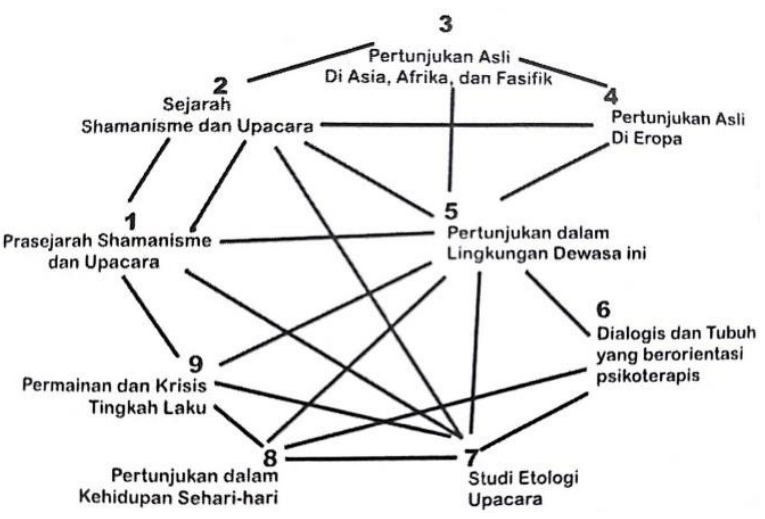

Gambar 1. Konsep Jaringan (The Web)

(Richard Schechner dalam Jaeni, 2014)

Konsep jaringan di atas kemudian digunakan untuk membaca aspek-aspek dalam seni pertunjukan, yang di antaranya: 1) aspek manusia; seniman/homocreator (manusia pencipta); seseorang yang memberi pengaruh besar dalam suatu kelompok, 2) aspek pertunjukan; prapertunjukan, pertunjukan, dan pascapertunjukan, 3) aspek penonton; penonton biasa dan penonton apresiator, dan 4) aspek manajemen.

\section{METODE PENELITIAN}

Pendekatan penelitian ini ialah kualitatif. Bogdan dan Taylor (dalam Moleong, 2021: 4) mengemukakan bahwa metodologi kualitatif adalah prosedur penelitian yang menghasilkan data deskriptif berupa kata-kata tertulis atau lisan dari orang-orang dan perilaku yang dapat diamati. Kiranya senada dengan itu, Moleong (2021: 6) berpendapat bahwa penelitian kualitatif ialah penelitian yang bermaksud untuk memahami fenomena tentang apa yang dialami oleh subjek penelitian misalnya perilaku, persepsi, motivasi, tindakan, dll., secara holistik, dan dengan cara deskripsi dalam bentuk kata-kata dan bahasa, pada suatu konteks khusus yang alamiah dan dengan memanfaatkan berbagai metode alamiah. Lebih lanjut, penelitian kualitatif tentunya menggunakan metode kualitatif pula, yang berupa pengamatan, wawancara, atau penelaahan dokumen (Moleong, 2021: 9). Penggunaan metode ini didasarkan pada apa yang disebut oleh Moleong bahwa lebih mudah apabila berhadapan dengan kenyataan jamak. Dalam praktiknya, Rohidi (2011: 171) berpendapat 
bahwa metode dapat diartikan sebagai suatu cara untuk bergerak atau melakukan sesuatu secara sistematis dan tertata, keteraturan pemikiran dan tindakan, atau juga teknik dan susunan kerja dalam bidang atau lapangan tertentu. Lebih lanjut ia mengatakan metode merupakan teknik atau peralatan khusus untuk menjelajah, memperoleh dan menganalisis informasi, misalnya penentuan objek, observasi, penggambaran, pemetaan, fotografi, video, audio, wawancara, studi kasus, survei, model, dan sebagainya.

Data yang didapat dikelompokkan menjadi dua, data primer dan data sekunder. Perihal yang tergolong data primer ialah rekaman wawancara dengan Syekh Din dan rekaman video pergelaran kesenian Sidalupa produksi Sanggar Buraq Lam Tapa. Sedangkan yang tergolong data sekunder ialah artikel maupun foto atau video terkait dengan objek yang tengah diteliti. Adapun tahapan penelitian yang akan dilaksanakan yakni sebagai berikut:

\section{Pengumpulan Data}

\section{1). Studi Pustaka/ Pengumpulan Data Dokumen}

Sebagai langkah awal, data dihimpun dengan melakukan studi pustaka. Studi kepustakaan bertujuan sebagai pijakan atau landasan awal peneliti dalam membangun asumsi atas objek/fenomena yang diteliti. Menurut Rohidi (2011: 206), teknik pengumpulan data dokumen biasanya digunakan untuk memperoleh informasi dari tangan kedua - kecuali jika memang dokumen itu sendiri yang menjadi sasaran kajiannya -, yang berbentuk berbagai catatan (perorangan maupun organisasi), baik resmi maupun catatan yang sangat pribadi dan mengandung kerahasiaan. Lebih lanjut Rohidi (2011: 206-207) melengkapi, informasi yang dikumpulkan antara lain berupa catatan perorangan (seniman, manajer pertunjukan, sesepuh masyarakat, dsb.), organisasi (daftar seniman yang terlibat, senarai pertunjukan yang telah dilakukan, jumlah karya seni dan coraknya, serta berbagai catatan, buku, leaflet, pamphlet, yang berkaitan dengan karya yang sedang dikaji. Rekaman audio dan video karya koleksi senimana bersangkutan, yang sekarang ini dapat diperoleh dengan mudah melalui internet. Adapun data yang telah didapat pada tahap ini berupa video pertunjukan kesenian Sidalupa produksi Sanggar Buraq Lam Tapa yang diunggah di beberapa akun dalam youtube. Sedangkan data penunjang lainnya ialah foto dan tulisan dalam bentuk buku, jurnal dan buletin.

\section{2). Observasi}

Metode observasi adalah metode yang digunakan untuk mengamati sesuatu, seseorang, suatu lingkungan, atau situasi secara tajam terinci, dan mencatatnya secara akurat dalam beberapa cara (Rohidi, 2011: 182). Sedangkan bagi peneliti sendiri, observasi atau mengamati adalah proses untuk mengetahui dan merasakan/mengalami secara langsung berbagai perihal atas objek yang tengah diteliti. Secara teknis, dalam proses mengamati, peneliti tidak melakukan kontak langsung dengan objek yang diamati - seperti tanya jawab dan semacamnya. Peneliti hanya akan mengindera dan memahami objek yang diteliti, serta bagaimana kaitan objek tersebut dengan perihal di luar "diri"-nya. Misalnya bagaimana kiat-kiat tokoh Sidalupa menghibur penontonnya dan bagaimana pula respon penonton terhadapnya. Dalam tahap ini, observasi akan dilakukan bersamaan di saat kesenian Sidalupa dipertunjukkan. Dengan begitu, peneliti dapat menyaksikan secara langsung serta memahami guna menjawab rumusan masalah yang diajukan dalam penelitian ini.

\section{3). Wawancara}

Pengumpulan data juga didukung dengan metode wawancara. Wawancara adalah suatu teknik yang digunakan untuk memperoleh informasi tentang kejadian yang oleh peneliti tidak dapat diamati sendiri secara langsung, baik karena tindakan atau peristiwa yang terjadi di masa lampau ataupun karena peneliti tidak diperbolehkan hadir di tempat kejadian itu (Rohidi, 2011: 208). Wawancara yang dimaksud ialah wawancara mendalam, dapat dikatakan lebih menyerupai sebuah percakapan, bukanlah wawancara yang terstruktur secara formal. Wawancara ditujukan pada seniman Sidalupa itu sendiri, yakni Syekh Din juga dengan beberapa anggota sanggarnya yang lain. Artinya, sebelum peneliti turun ke lapangan (pra penelitian), peneliti terlebih dahulu menentukan informan (seniman) yang dapat dimintai keterangannya.

\section{4). Perekaman}

Metode perekaman dapat dilakukan sejalan dengan metode observasi, bahkan menjadi alat utama dalam mengobservasi. Adapun bentuk perekaman yang dimaksud antara lain: fotografi, video, perekaman audio... (Rohidi, 2011: 194). Seterusnya Rohidi menekankan, teknik-teknik perekaman ini digunakan dalam penelitian seni karena dipandang lebih tepat, cepat, akurat, dan realistik berkenaan dengan fenomena yang diamati, jika dibandingkan dengan mencatatnya secara tertulis. Namun dalam pelaksanaannya, peneliti sendiri juga mencatat secara tertulis, khususnya data 
yang peneliti anggap lebing penting dibanding yang lain.

\section{Evaluasi Klasifikasi Data}

Setelah data dikumpulkan dengan cara studi pustaka (pengumpulan data dokumen), observasi, wawancara, dan perekaman. Barulah kemudian dilakukan evaluasi atau penilaian serta klasifikasi atau pengelompokan. Penilaian terhadap data bertujuan mengetahui mana data yang dapat dijadikan landasan atau pijakan argumen yang akan peneliti kemukakan, atau mana data yang dapat disampaikan meski sebatas informasi. Evaluasi sangat penting dilakukan karena besar kemungkinan peneliti mungkin saja secara tidak sengaja mendapat data-data yang tidak relevan. Selanjutnya barulah data-data yang telah dinilai tersebut diklasifikasi atau dikelompokkan berdasarkan kebutuhan, mana yang data primer dan mana yang sekunder.

\section{Menganalisis Menginterpretasi Data}

Menganalisis dapat dipahami sebagai upaya untuk mengungkap hal-hal di balik data yang tersaji. Menyelami data dari berbagai sisi, sehingga tidak ada celah yang luput dari analisa peneliti. Menelusuri kaitan antara satu data dengan data lainnya. Atau sebaliknya, menelusuri data yang sesunggunya tidaklah terkait. Bagian inilah terletak misteri yang patut diungkap oleh peneliti.

Tahap analisis dilakukan setelah data dihimpun dalam bentuk rekaman video, audio dan foto yang memuat video pertunjukan dan wawancara. Setelah melakukan proses analisis, barulah hasil atau temuan penelitian dapat dibahasakan sebagaimana pemahaman yang menjadi kesimpulan peneliti atas objek penelitiannya. Karena itulah yang menjadi tugas utama penelitian. Sebagaimana dikemukakan oleh Rohidi (2011: 48) tugas utama peneliti ialah menjelaskan secara teliti cara-cara orang yang berada dalam latar tertentu, karyakarya atau hasil dari tindakannya, sehingga dapat memahami, memperkirakan, mengambil langkahlangkah yang diperlukan.

\section{HASIL DAN PEMBAHASAN}

\section{Hasil}

Kesenian Sidalupa yang akan dibahas lebih jauh ialah produksi kelompok Buraq Lam Tapa, bertempat di Dusun Banda Layung, Desa Kuta Padang, Kec. Bubon - Aceh Barat. Alamat tersebut merupakan tempat di mana Syekh Din (Nurdin) tinggal. Di rumahnyalah segala atribut atau properti Sidalupa disimpan; topeng, kostum, topi, dan properti lainnya. Dan di rumah itu pula saya dan kolega (Hatmi Negria Taruan) bertemu untuk berbincang (wawancara) terkait Sidalupa dengan Syekh Din, juga ditemani seorang anggotanya, Rahmat Saputra (24 tahun).

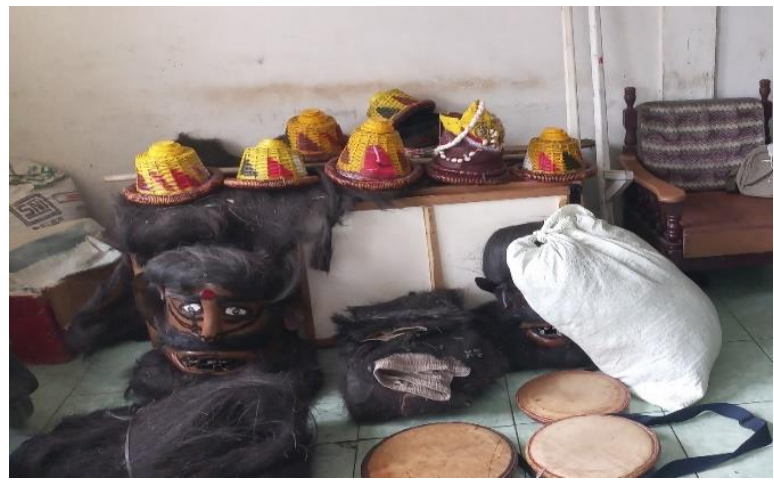

Gambar 2. Alat Musik, Topeng, Kostum, Topi, dan Beberapa Properti Pertunjukan Sidalupa (Susandro, 2021)

Seturut pembicaraan dengan Syekh Din, Nurdin merupakan nama panggilan oleh kawan-kawan sejawat, hingga di sepanjang perjalanan berkeseniannya, dipanggillah dengan Syekh Din, yang artinya seseorang yang ahli dalam sesuatu hal, dalam hal ini sebagai seniman Dalupa atau Sidalupa. Namun, berhubung pada suatu masa, di mana Syekh Din masih terbilang muda, Aceh sedang dalam masa gejolak yang cukup hebat. Terkadang hal-hal kecil menjadi sangat sensitif bagi kedua belah pihak yang sedang bertikai. Ditambah lagi, nama Nurdin cukup ramai melekat pada sebagian kaum laki-laki Aceh waktu itu. Maka dari itu, dan ketika itu, Nurdin ingin dipanggil sebagaimana nama aslinya, yaitu Dorahman Husin. Mulanya penulis masih ragu dengan pernyataan Syekh Din, terkait mana namanya yang sesungguhnya. Agar dapat menguatkan keterangan yang diberikan, Syekh Din pun menunjukkan beberapa kartu sebagai identitasnya, KTP (Kartu Tanda Penduduk), KIS (Kartu Indonesia Sehat), dan LVRI (Legiun Veteran Republik Indonesia). Seketika ketiga tanda pengenal itupun menyingkirkan keraguan di benak saya. Informasi lain yang ada di tanda pengenalnya, dituliskan bahwa Syekh Din lahir di Kuta Padang, namun tempat kelahiran sesungguhnya yakni di Samatiga, sebuah kecamatan yang hanya berjarak kurang dari 30 menit ke kecamatan Bubon, lokasi di mana saat ini Syekh Din tinggal. 


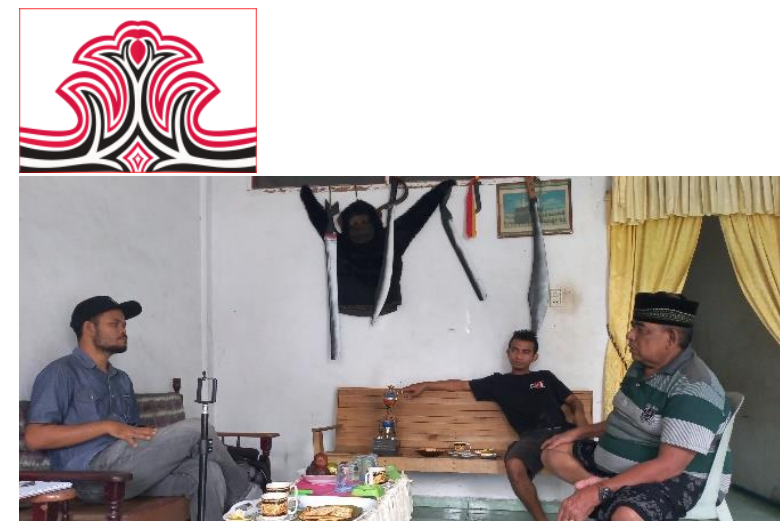

Gambar 3. Wawancara dengan Syekh Din (di Kediamannya) dan Rahmat Saputra (Susandro, 2021)

Dorahman Husin (Syekh Din aka Buraq Tapa) lahir pada tahun 1931 - sekiranya sekarang berumur 90 tahun - dari orang tua yang bernama Sulaiman (Ayah) dan Licin (Ibu). Kemudian Syekh Din pun memiliki istri bernama Cut Merah Gading. Dari pernikahannya dikaruniai sepasang anak yang bernaman Mariana (50 tahun) dan Samsuardi (46 tahun).

Di masa kecil, Syekh Din terlebih dahulu mengenyam pendidikan di sekolah Partikelir (swasta). Sekolah yang muncul di beberapa daerah di Nusantara pada masa Hindia Belanda (sebelum berganti nama menjadi Republik Indonesia). Pada masa itu, sekolah ini dikenal sebagai sekolah liar (sekolah pribumi tanpa izin) yang didirikan oleh para cendekiawan atau cerdik pandai yang tidak ingin bekerja pada pemerintah. Sehingga pada masa inilah pemerintah mengeluarkan peraturan (ordonansi) terkait sistem pendidikan bagi masyarakatnya, khususnya masyarakat pribumi. Karena pada masa itu pula, telah terjadi diskriminasi, seolah sekolah negeri hanya diperuntukkan bagi kalangan priyayi (historia.id).

Setelah mengenyam pendidikan di sekolah Partikelir, Syekh Din melanjutkan pendidikan di Sekolah Rakyat (SR). Kemudian diteruskan pula pada jenjang setelahnya yang disebut dengan PGA (Pendidikan Guru Agama) pada kisaran tahun 1954-1956, namun tidak sempat ia selesaikan. Di samping itu, Syekh Din menuturkan, juga sempat mengeyam pendidikan di pesantren.

Sebelum berkecimpung lama dengan kesenian Sidalupa, Syekh Din terlebih dahulu bersentuhan dengan kesenian Seudati, hingga 33 tahun lamanya. Dalam rentang waktu tiga dekade itu pula ia mendapat gelar Syekh, yang artinya seseorang yang ahli dalam suatu hal (tari seudati). Dengan semangat Syekh Din menambahkan bahwa dalam rentang waktu sebagai penari seudati-lah ia dijuluki dengan nama Buraq Tapa, karena menurut orang-orang yang melihatnya (yang memberi julukan), Syekh Din bergerak sangat gesit, lincah, secepat kilat bagaikan Buraq (kendaraan yang digunakan oleh Nabi Muhammad SAW ketika Isra' dan
Gorga : Jurnal Seni Rupa

Volume 10 Nomor 02 Juli-Desember 2021 p-ISSN: 2301-5942 | e-ISSN: 2580-2380

Mi'raj). Sedangkan Tapa (bahasa Aceh) artinya bertapa atau "berdiam diri", dengan kata lain Syekh Din mengumpamakan seseorang yang sedang be-ratib (berzikir, bersalawat, juga berdo'a). Lebih lanjut, pengakuannya sebagai penari seudati dibuktikan dengan menunjukkan tropi dari lomba yang pernah diikuti sekaligus dimenangkannya sebagai penampil terbaik.

Di tengah upayanya menekuni seni tari Seudati, pada tahun 1961, Syekh Din pertamakali mengenal Sidalupa - perwujudannya dalam bentuk tarian (namun ia menegaskan telah mengetahui kisah Sidalupa sejak dirinya masih kecil, melalui cerita orangtua masa itu). Pada tahun tersebut, Syekh Din (kembali) mendengar kisah Sidalupa secara langsung dari pelaku kesenian Sidalupa itu sendiri, yaitu seseorang yang dalam kesehariannya biasa dipanggil Ayah Wah Teuku Kama (pemain serune kalee) dan Muhammad Rachid (pemain gendang tambuh). Seturut keterangan Syekh Din, dari kedua tokoh di ataslah ia memiliki pengetahuan tentang kisah Sidalupa dan belajar bagaimana menyajikan pertunjukannya. Syekh Din pun menegaskan bahwa ia hanya bermain dengan beberapa kelompok sewaktu masih menekuni (sebagai penari) seudati. Sedangkan dalam rentang waktu ia sebagai pelaku kesenian Sidalupa, tidak pernah sekalipun bergabung dengan kelompok lain.

Bersebab informasi yang digali berdasarkan pada ingatan serta mengingat usia informan yang hampir genap dalam hitungan abad, sulit bagi peneliti mendapat data yang terperinci, terutama bagaimana Syekh Din belajar praktik kesenian Sidalupa. Berdasarkan informasi yang diberikan, penulis membayangkan bahwa Syekh Din tentunya belajar tidaklah secara formal, seperti halnya sekolah-sekolah. Melainkan dengan cara mengobrol dengan tetua dalam waktu senggang, mengamati para tetua tersebut bermain, dan mencoba (mungkin sekali-kali) bergabung di dalamnya, terutama di saat pertunjukan digelar; khususnya sebagai pemusik. Melalui rentang proses inilah sekiranya Syekh Din mendapat bekal untuk mendirikan kelompoknya sendiri.

Setelah tiga dekade dikenal sebagai penari seudati, yang dalam rentang waktu itu pula Syekh Din mendapat "kepandaiannya yang lain". Pada tahun 1999, Syekh Din mendirikan kelompok Sidalupa bersama beberapa kawannya yang kemudian diberi nama Buraq Lam Tapa. Sebuah nama yang diambil sedikit dikembangkan - dari julukannya, Buraq Tapa. Kata lam (bahasa Aceh) berarti dalam, yang apabila diartikan secara keseluruhan, Buraq Lam Tapa berarti 
Gorga : Jurnal Seni Rupa

Volume 10 Nomor 02 Juli-Desember 2021

p-ISSN: 2301-5942 | e-ISSN: 2580-2380

Buraq dalam pertapaan (ratib: berzikir, bersalawat, juga berdo'a). Penambahan kata lam dimaksudkan bukan sebagai keterangan tempat, melainkan kata kerja.

Mulanya, sebelum melakukan kontak, baik melalui telepon atau wawancara langsung dengan Syekh Din, penulis mengira Buraq Lam Tapa merupakan nama kelompok sekaligus julukan yang melekat padanya. Namun, pada saat melakukan kontak pertama kali melalui telepon, Syekh Din pun sedikit berkisah dan menegaskan bahwa "Buraq Lam Tapa adalah nama kelompok, sedangkan Buraq Tapa adalah julukan yang diberikan kepada saya" (wawancara melalui telepon, tanggal 4 Juli 2021, Pkl 16.16 WIB).

Sejak dari tahun pendirian hingga dewasa ini, jumlah anggota kelompok Buraq Lam Tapa tidaklah tetap. Terkadang berjumlah empat belas orang, dan di suatu ketika ada pula hanya berjumlah sebelas orang. Saat ini anggota yang tetap hanya berjumlah lima orang, di antaranya: Syekh Din (90 tahun), Sulaiman Rus, Aidarus, Rahmat Saputra (24 tahun), dan T. Zul Akli. Sedangkan anggota lain yang tidak tetap ialah Basri (24 tahun); bekerja di kebun sawit, Kia (19 tahun); pelajar SMA, Kemal, dan Jubrani (30 tahun); toke sawit.

Seturut keterangan dari Syekh Din, anggota tetap ini merupakan dari keluarga sendiri misalnya anak. Di setiap pergelaran, anak laki-laki Syekh Din juga turut serta ambil bagian, khususnya sebagai pemain gendang. Sedangkan anggota tetap lain juga berasal dari keluarga, setidaknya saudara dekat. Ataupun kalau tidak, saudara jauh juga dapat menjadi anggota tetap, berlandas kepercayaan kepada saudara tersebut. Seperti halnya Rahmat Saputra, ia mengakui - katakanlah sebagai keluarga jauh dari Syekh Din. Namun karena ia dianggap berbakat dalam seni perkusi, maka Rahmat diajak untuk bergabung menjadi anggota tetap.

Meski terkadang jumlah anggota yang mengalami pasang-surut, setidaknya dapat mengakomodir berbagai kebutuhan yang dibutuhkan untuk melaksanakan pergelaran. Sekiranya komposisi pemain yang harus ada dalam mengadakan pergelaran Sidalupa ialah dua orang pemeran Sidalupa, satu orang sebagai kera, ditambah satu orang lagi sebagai geunteut (sesosok makhluk gaib; hantu, berwujud hitam dan berukuran tinggi besar). Sedangkan pemusiknya terdiri dari pemain serune kalee, rapai, tamboh (gendang), canang (gong), gerdam mamba (tamboh pendek), boh grik-grik (marakas). Satu di antara alat musik tersebut di atas yang terbilang asing ialah "marakas", dalam bahasa Aceh Syekh Din menyebutnya dengan boh grikgrik (buah grik-grik), karena suara/bunyi yang dihasilkan terdengar seperti "grik-grik". Alat musik Marakas bukanlah asli produk budaya masyarakat Aceh, melainkan berasal dari daratan Afrika. Syekh Din tertarik pada alat ini ketika melakukan perjalanan (mengikuti perlombaan) ke Sumatera Utara, seingatnya sekitar tahun 2017. Menurutnya alat musik ini menghasilkan suara/bunyi yang khas - mirip dengan alat yang sebelumnya telah lama pula digunakan (terbuat dari kaleng yang berisikan kelereng). Dengan energik Syekh Din pun memainkan alat musik ini di setiap kesempatan pergelaran Sidalupa, tubuhnya pun bergoyang mengikuti gerakan serta tempo kedua tangan.

Di samping karena kisah singkatnya di atas pertemuan dengan marakas, Syekh Din beranggapan dalam penyajian kesenian Sidalupa hendaknya inovasi dilakukan, khususnya dalam hal musik iringan. Syekh Din pun menekankan, itu bagian dari kreativitas dan imajinasi. Dalam hal itu, tentu penulis atau seniman manapun sangat bersepakat dengan pernyataan serta inovasi demikian. Karena pernyataan serta perlakuan yang demikian terhadap kesenian (tradisional), mengindikasikan kesenian tersebut akan lama mengendap serta terajut di sepanjang kehidupan masyarakat pemiliknya.

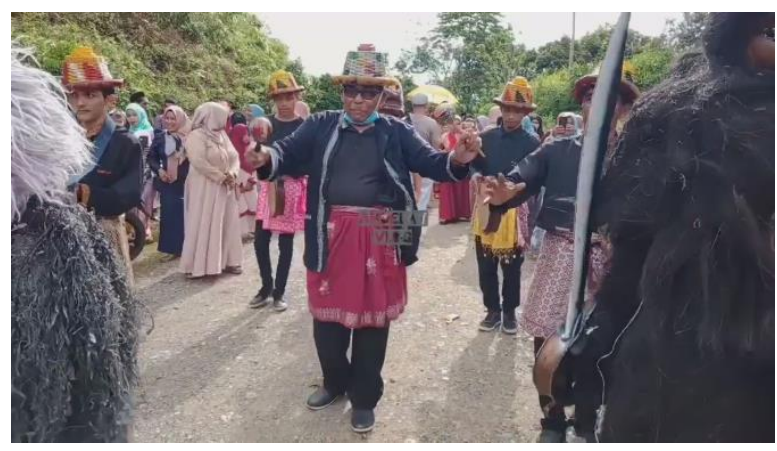

Gambar 4. Syekh Din Buraq Tapa (Berkacamata Hitam) Memainkan Alat Musik Boh Grik-Grik (Susandro, 2021)

Tidak hanya pada alat musik saja, inovasi juga dilakukan oleh Syekh Din pada kostum Sidalupa. Syekh Din menuturkan bahwa pada mulanya kostum Sidalupa terbuat dari on krusong (daun pisang kering). Sedangkan topeng yang digunakan mulanya terbuat dari jantung pisang, karena dahulunya pisang-pisang yang tumbuh berukuran besar, tentu begitu pula dengan jantung, daun dan sebagainya. Ia menambahkan, satu kelopak jantung pisang dapat menutupi seluruh muka orang dewasa, bahkan melebihi sehingga dapat terlihat menyeramkan atau semacamnya. Selain itu, dahulunya para seniman Sidalupa juga menggunakan pelepah rumbia sebagai topeng, sedangkan bajunya terbuat dari kulit kayu tarok. Sekali lagi, karena perlu adanya kreasi serta inovasi, maka - seturut penuturan Syekh Din - ia 
Gorga : Jurnal Seni Rupa

Volume 10 Nomor 02 Juli-Desember 2021

p-ISSN: 2301-5942 | e-ISSN: 2580-2380

menggagas agar topeng Sidalupa terbuat dari kayu rubek dan kostumnya dari ijuk. Kayu rubek dipilih karena materialnya lunak dan cenderung mudah untuk diukir dan semacamnya. Sedangkan ijuk tampak lebih representatif sebagai penanda bulu-bulu yang lebat di tubuh Sidalupa.

Sepengetahuan penulis, saat ini, seluruh anggota Buraq Lam Tapa tidak satupun terlihat (pada video dalam youtube) menggunakan kostum (baju) dari kulit kayu tarok. Namun penggunaan kostum dari bahan tersebut dapat dilihat pada kelompok Sanggar Seni Datok Rimba (SSDR) di Desa Suak Trieng, Woyla, Aceh Barat. Apakah mungkin, Sanggar Seni Datok Rimba memberi pengaruh (dalam hal penyajian Sidalupa) pada Buraq Lam Tapa? Karena bila merujuk pada waktu pendirian kelompok masing-masing, SSDR berdiri pada tahun 1981, delapan belas tahun lebih tua dari Buraq Lam Tapa. Ditambah pula Hanafiah (salah satu pendiri SSDR) pernah menyatakan bahwa dulunya, dalam waktu yang tidak lama, Syekh Din juga merupakan anggota SSDR (Susandro, 2021: 17). Namun dalam sebuah wawancara yang penulis lakukan dalam waktu dekat ini, secara tidak langsung pernyataan tersebut dibantah oleh Syekh Din, bahwa ia tidak pernah bergabung dengan kelompok Sidalupa lainnya, kecuali di saat dirinya sebagai penari seudati. Meski demikian, terlepas benar tidaknya kesaksian yang diberikan kedua seniman tersebut, suka-tidak suka, satu di antara ke-dua-nya telah memberi pengaruh sehingga kesenian Sidalupa ini dapat berkembang luas, khususnya di lingkup masyarakat Aceh Barat. Tentunya perihal tersebut merupakan pengaruh baik yang layak untuk diapresiasi.

Selain dari alat musik serta kostumnya yang khas atau berbeda dengan yang lain, Syekh Din atau kelompok Buraq Lam Tapa juga memiliki kisah Sidalupa versi mereka sendiri, yang dipercaya benar adanya, bukan cerita fiktif atau karangan belaka. Persamaannya dengan SSDR adalah sama-sama mempercayai/ meyakini bahwa kisah Sidalupa yang mereka ceritakan benar adanya, meski kedua kisah yang mereka ceritakan memiliki tokoh dan alur yang sangat berbeda Kisah Sidalupa versi SSDR dapat dilihat pada artikel yang penulis (beserta kawan-kawan) tulis sendiri berdasarkan wawancara langsung dengan Hanafiah, berjudul "Dramaturgi Kesenian Tradisional Dalupa Produksi Sanggar Seni Datok Rimba di Woyla Aceh Barat", diterbitkan oleh junal Gorga, Unimed, Vol. 10, No. 01, tahun 2021. Sedangkan kisah Sidalupa versi Buraq Lam Tapa yang juga penulis dengar langsung dari Syekh Din yang kemudian penulis parafrasa-kan ialah sebagai berikut:
Kisah bermula pada sebuah kerajaan di Hindia, di mana seorang raja yang tengah murka kepada - katakanlah semacam pegawai kerajaan yang bernama Sidal dan Upa yang dutuduh telah berbuat curang. Hukuman yang dijatuhkan pun tidak tanggung-tanggung, yakni hukuman mati digantung. Jelas saja keduanya begitu ketakutan, hingga memutuskan melarikan diri dari jerat tiang gantungan. Agar terjamin bahwa mereka akan aman tanpa dikejar-kejar pengawal kerajaan, keduanya lari menggunakan sampan (perahu kecil) puntung menyebrangi laut. Di tengah laut, sampan mereka dihembus angin puting beliung hingga sampailah ke pulah weh atau we (bahasa Aceh, yang berarti pergi. Pulau kecil yang terpisah - dulunya tergabung - dengan pulau Sumatera akibat letusan gunung merapi), di mana terletaknya kota Sabang. Tidak sampai di situ, sampan yang mereka naiki terus dihembus angin kencang hingga sampai di laut Sumatera bagian barat. Dari kejauhan keduanya melihat pohon arun (pinus), akhirnya mereka memutuskan untuk menepi menuju pantai, menyusuri sungai-sungai.

Karena masih dirundung rasa ketakutan, kedunya terus lari ke pedalaman hutan yang berbukit hingga sampai pula di sebuah gua, mereka pun memutuskan untuk istirahat dan akhirnya tinggal di sana. Setelah sekian lama dan dalam kondisi demikian, tentu saja badan mereka tidak lagi terurus. Di sekujur tubuh mereka ditumbuhi bulu-bulu yang sangat lebat. Sedangkan di bibir gua, kera-kera mengeluarkan suara berisik sambil bergayut di pohon rotan - seolah melihat makhluk asing atau musuh yang mengancam. Semakin lama, keberadaan makhluk asing tersebut diketahui juga oleh orang-orang pencari rotan. Merekapun mengabari masyarakat lain yang ada di kampung. Beberapa orang penduduk kampung pun berjalan menyusuri hutan untuk membujuk makhluk tersebut agar mau keluar dari gua. Berbagai cara telah dilakukan, namun tidak satupun yang berhasil. Pada akhirnya, penduduk kampung menggunakan kaca - dihadapkan pada makhluk tersebut - seolah mereka melihat sesosok yang sama pula dengan mereka. Bersamaan dengan itu, upaya bujukan tersebut ditambah pula dengan iringan musik serune kalee. Akhirnya makhluk itupun terpancing dan mau keluar. Syekh Din menjelaskan, relevansi suara musik serune kalee sebagai alat pancingan ialah karena asal-usul makhluk (kedua orang; Sidal dan Upa) tersebut dari India, maka dari itu makhluk itupun tertarik untuk keluar.

Seturut keterangan Syekh Din, cukup jauh makhluh itu keluar, bahkan sampai ke pinggiran kampung. Namun pada akhirnya, makhluk itu sadar bahwa mereka tengah dipancing agar mau keluar. Keduanya lari kembali ke 
dalam gua, hingga pada suatu ketika, penduduk kampung menemukan keduanya telah menjadi bangkai di dalam sana. Dengan cepat kabar pun sampai ke seluruh penduduk kampung, hingga kisah tentang keberadaan Sidal dan Upa diceritakan pula oleh para orang tua pada anak-anaknya dan terus sampai di telinga penduduk kampung sekarang ini.

Beranjak dari kisah di atas, Syekh Din menyatakan bahwa pertunjukan tari Sidalupa yang dilihat sekarang ini merupakan suatu gambaran ulang peristiwa di mana penduduk kampung membujuk Sidal dan Upa agar keluar dari dalam gua. Sama dengan sebelumnya, bagaimana alur kisah Sidalupa dan kemudian kaitannya dengan pergelaran-nya terdengar cukup masuk akal. Namun sekali lagi, ke-logis-an sebuah cerita yang terlihat dari alurnya yang cukup runtut serta berdampak nyata bagi masyarakat (terbentuknya kesenian Sidalupa) tentu belum cukup untuk dijadikan sebagai bukti bahwa kisah tersebut nyata atau benar adanya. Kendati demikian, tidak pula penulis berkesimpulan bahwa kisah tersebut mengada-ada. Melainkan tetap beranggapan, mungkin saja benar mungkin pula tidak. Karena dengan beranggapan demikian, kisah Sidalupa tetap menjadi misteri atau teka-teki yang selalu membuatnya menjadi menarik untuk diselisik.

\section{Pembahasan}

Membaca pergelaran Sidalupa dalam 'konsep jaringan' (the web) Richard Schechner, terdapat beberapa aspek yang akan dipaparkan. Aspek-aspek ini merupakan titik-titik yang saling bertaut, bersilang, mempengaruhi, hingga memberi dampak pada titik/aspek yang lain. Adapun bagaimana pertautan masing-masing aspek tersebut ialah sebagai berikut:

Aspek manusia: seniman/homocreator (manusia pencipta). Berpijak pada paparan di atas, menunjukkan bahwa peranan seseorang (seniman/kreator) dalam suatu kelompok cukup besar pengaruhnya terhadap kelompok tersebut; terutama dalam hal nilai yang terkandung, kisah yang diyakini/percayai, gaya penyajian, hubungan seniman atau kelompoknya dengan penonton yang kemudian berdampak pula pada regulasi pelaksanaan pergelaran. Apabila hubungan antara seniman dengan penonton berjalan dengan baik, maka penghargaan (apresiasi) masyarakat pun tumbuh semakin besar, seperti mengundang kelompok Sidalupa untuk berpentas.

Contoh lain misalnya bagaimana sepenggal kisah awalmula Sidalupa. Syekh Din mempercayai sebuah kisah yang alurnya jelas sangat berbeda dengan kisah yang beredar di tengah masyarakat atau dengan yang dipercayai seniman Sidalupa dari kelompok lainnya.
Tentunya perihal apa yang dipercayai Syekh Din, begitu pula dengan anggota kelompoknya. Sistem kepercayaan semacam ini juga berlaku pada kelompok Sidalupa lainnya, yakni Sanggar Seni Datok Rimba yang berada di Desa Suak Trieng, Kecamatan Woyla.

Aspek pertunjukan: prapertunjukan, pertunjukan, pascapertunjukan. Sepanjang tanya-jawab penulis dengan Syekh Din, juga dengan seorang anggotanya; Rahmat, secara singkat mereka menerangkan bahwa proses sebelum pertunjukan, pertunjukan, dan setelah pertunjukan - tidak dilakukan secara terpola atau tersistematis. Sekiranya ketiga tahapan tersebut dapat direntangkan sebagai berikut. Dimulai dari adanya permintaan atau undangan. Syekh Din akan bernegosiasi dengan tuan rumah/ pelaksana acara terkait 'biaya jemputan'. Bersamaan dengan itu, negosiasi juga dilakukan dengan anggota, apakah cocok dengan biaya yang ditawarkan. Seperti biasa, pada tahap ini akan ada proses tawar menawar hingga sampai pada kesepakatan dari kedua belah pihak. Seturut pengakuan Syekh Din, kelompoknya biasa dibayar 3,2 juta selama sehari (pagi sampai sore). Namun apabila sehari-semalam, bayarannya menjadi 6 jutaan.

Persiapan sebelum pentas pun tidaklah serumit yang penulis bayangkan - laiknya seni pertunjukan moderen, karena segala kebutuhan: kostum, properti, topeng, alat musik dan sebagainya sudah tersedia dan terkumpul pada suatu tempat, yakni di rumah Syekh Din sendiri. Jadi, seturut pernyataan Rahmat, apabila sanggar Buraq Lam Tapa akan berpentas, setiap anggota akan berkumpul dan berlatih selama kurang lebih dua jam, sehari atau dua hari sebelum acara. Proses latihan yang terbilang sangat singkat demikian dapat dikatakan cukup wajar dan sepadan, karena di saat pertunjukan berlangsung, tidak terlihat teknik-teknik yang rumit atau pola-pola tertentu sehingga membutuhkan waktu persiapan atau latihan yang panjang pula. Ditambah lagi, karena masing-masing pemain telah menguasai apa-apa yang dibutuhkan sebagaimana telah ditetapkan dari semula. Selebihnya, pada pertunjukan-pertunjukan Sidalupa kedepannya, semacam repetisi gaya penyajian yang telah dilakukan sebelumnya. Tidak ditemukan kreasi di setiap dilakukannya pergelaran. Dalam perkataan lain, seolah kerasi dirasa cukup apabila pergelaran yang disajikan berbeda dengan penyajian kelompok lain, setelah itu, hanyalah pengulangan. Kesederhanaan prosesi di atas terasa lebih singkat di saat acara telah berakhir. Semua pemain kembali pada titik kumpul, rumah Syekh Din, dan merapikan segala peralatan pementasan; menyusun, mengikat, dan ada pula yang digantung di dinding. Honor pun kemudian dibagi berdasarkan kebijakan dari Syekh Din sendiri 
serta dengan beberapa para tetua yang lain, yang tidak etis pula penulis tanyakan secara mendetail. Meski proses yang dilalui terbilang sederhana, perihal yang paling esensial ialah pergelaran yang dilakukan kelompok ini berlangsung dalam waktu yang cukup lama, yang didorong oleh kecintaan terhadap seni tradisi pula.

\section{Aspek penonton: penonton biasa, penonton} apresiator. Kesenian Sidalupa tidak dihidupkan sepenuhnya oleh senimannya, melainkan juga oleh masyarakat penontonnya. Bersebab sinergi-peran dari keduanyalah kesenian ini dapat bertahan hingga sekarang. Di satu sisi, seniman Sidalupa terbilang jarang melakukan pertunjukan tanpa didasari adanya keuntungan materil. Alasan tersebut dapat dimaklumi, karena di sepanjang hari, hampir seluruh anggota kelompok kesenian ini berprofesi sebagai petani atau buruh di sebuah pabrik sawit yang ada di kampung. Tentunya dari sana dapat dipahami pula jangkauan ekonomi para pelaku kesenian ini. Di lain sisi, karena adanya minat dari masyarakat - dengan anggapan bahwa kesenian Sidalupa merupakan kesenian milik masyarakat, juga sebagai identitas masyarakat Aceh Barat, maka kelompok-kelompok Sidalupa, khususnya Buraq Lam Tapa, memiliki alasan pula untuk terus dapat melakukan pergelaran. Dengan kata lain, ada undangan atau permintaan, maka ada pula pergelaran.

Acara yang diisi pun beragam: acara pernikahan, sunat rasul, akikah anak, pawai, kampanye, dan lain sebagainya. Dapat dikatakan, kesenian Sidalupa hampir dapat ditampilkan di setiap acara yang dilaksanakan masyarakat, karena baik secara estetik (nilai) maupun artistik (bentuk), bagaimanapun beragamnya, kesenian Sidalupa tidak bertentangan dengan ajaran Islam. Ditambah lagi, penyajiannya dalam bentuk tarian yang tidak terpola atau menggunakan teknik-teknik tertentu - karena memang begitu pula adanya, membuat pemain dapat mobile (berpindah tempat) atau dapat menyesuaikan dengan berbagai kondisi yang ada; tampil di atas panggung, halaman rumah, tanah lapang, bahkan jalan beriringan di jalan raya.

Menyinggung lebih jauh keterkaitan kesenian Sidalupa dengan Syariat Islam, seturut pernyataan Syekh Din, kesenian Sidalupa yang dilakoninya sama sekali tidak bersinggungan dengan hal gaib (mistik), dan tidak pula bertentangan dengan syariat Islam. Dalam pelaksanaan pertunjukannya, tidak pula menggunakan hal-hal yang identik dengan itu, seperti membakar kemenyan dan sebagainya. Pernyataan tersebut senada pula dengan
Gorga : Jurnal Seni Rupa

Volume 10 Nomor 02 Juli-Desember 2021 p-ISSN: 2301-5942 | e-ISSN: 2580-2380

keterangan dari Hanafiah SSDR, yang secara tegas menjawa 'tidak ada' di saat penulis menanyakan hubungan kesenian Sidalupa dengan hal mistik. Bahkan Hanafiah menambahkan, kisah Sidalupa versi SSDR sangat dekat dengan perihal Islami, karena juga mengisahkan awal-mula masuknya Islam di Woyla, Aceh Barat. Jawaban dari kedua pelaku di atas cukup masuk akal, karena kalau bertentangan dari Syariat Islam, tentu kesenian ini akan sulit mendapat tempat di tengah masyarakat. Selain itu, merujuk pada video pertunjukan Sidalupa yang cukup masif tersebar di internet, khususnya kelompok Buraq Lam Tapa dan SSDR, tidak pula ditemui perihal yang penulis pertanyakan.

Selain sinergi-peran antara pemain dan penonton, kontestasi antara setiap kelompok yang ada pada dasarnya juga menjadi pemicu atau daya dorong yang kemudian muncul pemahaman di masing-masing kelompok, "bagaimana caranya menjadi lebih baik dari kelompok yang lain.” Kontestasi yang dapat terbaca oleh penulis ialah terjadi antara kelompok Buraq Lam Tapa dengan kelompok Sidalupa Datok Rimba. Di mana di satu sisi, dalam sebuah wawancara Hanafiah menyatakan bahwa dulunya Syekh Din merupakan anggota dari kelompoknya (Susandro, 2021: 17). Sedangkan secara tidak langsung (dalam sebuah wawancara pula) Syekh Din membantahnya. Di sisi lain, kelompok Datok Rimba berdiri dalam rentang waktu yang cukup jauh sebelum berdirinya Buraq Lam Tapa dan disampaikan pula oleh Syekh Din, bahwa sebelum ia menggunakan kostum dari bahan ijuk, dulunya seniman Sidalupa juga menggunakan kostum yang terbuat dari kayu tarok, bahan yang saat ini masih terlihat digunakan oleh kelompok Sidalupa Datok Rimba yang dipimpin oleh Hanafiah. Perihal demikian secara sadar dan sengaja penulis paparkan dengan maksud bukan "memperuncing" perbedaan di antara keduanya. Melainkan mengemukakan bahwa di sisi lain perbedaan demikian justru berdampak positif bagi keberadaan dan keberlangsungan kesenian Sidalupa itu sendiri.

Masyarakat penonton Sidalupa ini sesungguhnya tidak dapat dibagi secara hitam dan putih, mana penonton biasa dan mana penonton apresiator. Kalaupun harus dipilah, melihat dari tingginya antusias masyarakat, penulis menilai masyarakat cenderung melakoni peran sebagai penonton apresiator. Pertama, apresiasi dalam bentuk undangan/mengundang kelompok Sidalupa agar dapat tampil. Kedua, adakalanya pelaku seni Sidalupa itu sendiri bertindak sebagai penonton apresiator. Jika penonton biasa cenderung pasif, 
menonton sekadar untuk mencari hiburan. Sebaliknya, penonton apresiator cenderung aktif atau bahkan kreatif. Di samping terkadang juga bermaksud mencari hiburan, tujuan utama penonton kreator dalam menonton suatu pertunjukan ialah untuk mengetahui apapun yang terkait dengan pertunjukan yang sedang ditontonnya. Hingga kemudian memberi dampak pada dirinya, dapat menghasilkan kebaruan dalam karyanya atau berkemungkinan dapat pula menghasilkan kisah yang berbeda dari sebelumnya. Seperti yang dilakukan oleh Syekh Din, seturut pengakuannya, bahwa dirinyalah yang pertamakali menggunakan kostum Sidalupa; topeng yang terbuat dari kayu tarok serta baju yang berbahan ijuk. Tentu kerasinya tersebut didasari pula oleh bentuk kostum sebelumnya yang terbuat dari daun pisang kering.

Aspek manajemen. Seturut keterangan Syekh Din, manajemen atau tata kelola yang diterapkan dalam kelompoknya tidaklah mengacu pada sistem manajemen moderen, baik struktur organisasi serta bagaimana tahapan pelaksanaan pertunjukannya. Adapun sistem tatakelola moderen terdiri dari empat tahapan: planning (perencanaan), organizing (pembagian kerja), actuating (pelaksanaan), dan controlling (mengontrol). Penataan yang ada dalam kelompok terbilang sederhana, yakni Syekh Din selaku tetua dan pemimpin dalam kelompok dan selebihnya sebagai anggota. Ada waktunya Syekh Din mengambil keputusan yang kemudian diikuti oleh anggotanya dan ada pula waktunya keputusan diambil berdasarkan hasil musyawarah. Di samping itu, yang menarik dari sistem tata kelola yang diterapkan oleh Syekh Din dalam kelompoknya; Buraq Lam Tapa - begitu pula halnya dengan kelompok Sanggar Seni Datok Rimba - ialah setiap pemain diarahkan untuk tetap konsisten dengan peran atau posisinya yang telah digeluti dari semula. Misalnya, pemain musik serune kalee sulit bahkan tidak pernah diizinkan untuk berperan sebagai Sidalupa. Karena dalam suatu kelompok, jarang yang memiliki kemampuan ganda. Maka apabila seorang pemain berpindah peran, tidak ada yang akan menggantikan tempat kosong yang ditinggalkan. Kalaupun ada, posisi yang akan ditinggalkan bukanlah posisi yang vital - berdampak besar saat pergelaran.

\section{KESIMPULAN DAN SARAN}

\section{Kesimpulan}

Pembacaan terhadap keempat aspek yang telah dilakukan, berlandaskan pada 'konsep jaringan' Richard Schechner, cukup dapat menyingkap tabir di balik pergelaran kesenian Sidalupa. Seperti sebabsebab yang melatari perwujudan gaya penyajian oleh Syekh Din, serta kaitannya dengan seniman terdahulu atau yang sezaman dengannya. Aspek luar pertunjukan menjadi bagian yang tidak terbaca, namun berpengaruh besar terhadap apa-apa yang terlihat oleh penonton.

\section{DAFTAR RUJUKAN}

Dadek, Teuku. (2015). Asal-usul Aceh Barat. Aceh Bar at: Badan Perencanaan dan Pembangunan Daerah.

Jaeni. (2014). Kajian Seni Pertunjukan dalam Perspektif Komunikasi Seni. Bogor: IPB Press.

Moleong, Lexy, J. (2021). Metodologi Penelitian Kualitatif Edisi Revisi. Bandung: PT. Remaja Rosdakarya.

Pramayoza, Dede. (2013). Strategi Membaca 'Pergelaran', Seorang Antropolog, dan Sebuah Mozaik Penelitian, dalam Pergelaran: Sebuah Mozaik Penelitian Seni-Budaya. Yogyakarta: Jalasutra.

RN, Herman. (2016). Dalupa: Teater Tradisional Pantai Barat. Buletin Tuhoe edisi VII Banda Aceh: JKMA Aceh.

Rohidi, Tjetjep Rohendi. (2011). Metodologi Penelitian Seni. Semarang: Cipta Prima Nusantara Semarang.

Susandro. (2021). Geliat Kesenian Tradisional Dalupa di Aceh Barat. Banda Aceh: Balai Pelestarian Nilai Budaya Aceh. https://bulletinhaba.kemdikbud.go.id/index.p hp/haba/issue/view/4/36

Susandro. (2021). "Wawancara Syekh Din dan Rahmat Saputra”. Hasil Dokumentasi Pribadi: 11 Juli 2021, Aceh Barat.

Susandro, Wirandi, Rika., \& Taruan, Hatmi Negria. (2021). Dramaturgi Kesenian Tradisional Dalupa Produksi Sanggar Seni Datok Rimba di Woyla Aceh Barat. Gorga: Jurnal Seni Rupa, $\quad 10 \quad$ (1), 15-23. https://doi.org/10.24114/gr.v10i1.22730 